\title{
FATORES DE INIBIÇÃO NA COMPRA ON-LINE
}

\author{
Luís Cavadas ${ }^{1}$ \\ Susana Costa e Silva ${ }^{2}$ \\ Carla Martins $^{3}$ \\ António Andrade ${ }^{4}$
}

\begin{abstract}
Resumo: O objetivo deste trabalho consiste em identificar as barreiras ao comércio eletrónico em Portugal, face a outros países europeus. Foi adotado um modelo para compreender a variação das práticas de comércio eletrónico em Portugal com base em quatro dimensões: Risco Percebido, Facilidade de Uso Percebida, Utilidade Percebida, e Experiência Online. Este modelo foi testado numa amostra de 101 indivíduos, tendo sido possível encontrar uma correlação positiva entre as práticas de comércio eletrónico e a facilidade de utilização percebida, a utilidade percebida e a experiência online.
\end{abstract}

Palavras-chave: Comércio Eletrônico, Risco Percebido, Utilidade Percebida, Experiência Online

\begin{abstract}
The purpose of this paper is to understand the obstacles to e-commerce in Portugal compared to other European countries. In order to understand the variation of the e-commerce practices in Portugal, a model was proposed. In this model four constructs were used as explanatory variables: Perceived Risks; Perceived Ease of Use; Perceived Usefulness; and Online Experience. This model was tested in a sample of 101 respondents which allowed finding a positive correlation between the E-commerce Practices and the Perceived Ease of Use, the Perceived Usefulness, and the Online Experience constructs.
\end{abstract}

Keywords: E-Commerce, Perceived Risk, Perceived Usefulness, Online Experience

\footnotetext{
${ }^{1}$ Católica Porto Business School

${ }^{2}$ CEGE, Católica Porto Business School

${ }^{3}$ CEGE, Católica Porto Business School

${ }^{4}$ CEGE, Católica Porto Business School. Email: aandrade@porto.ucp.pt
} 


\section{INTRODUCTION}

In a study conducted by EuroStat in 2014, Portugal was considered to have a high internet penetration rate. The same study revealed that the population used the internet at least on a weekly basis, which could lead to the thought that online purchases would be high as well (EuroStats, 2014). However, the reality is that the Portuguese do not use the internet for purchasing activities as much as they should when considering their online practices. Why are then the Portuguese so unwilling to buy online when compared to other countries in EU27, such as $87 \%$ in the United Kingdom (EuroStats, 2015)? What are the variables that contribute to this phenomenon?

There aren't many studies about the e-commerce business in Portugal with significant findings regarding the influencing variables and barriers. Furthermore, in the literature, findings regarding the correlations between the online purchasing habits and other variables are not certain, as many of them seem to have mixed findings. Thus, understanding these relations deserves further development for this reason as well.

In fact, the Portuguese demographic characteristics, habits, and thoughts might influence the e-commerce practice in different ways. However, other factors may also exert an influence: the perception of the many risks presented in e-commerce, or the difficulties using this new technology might be behind the low online purchases. Furthermore, in comparing Portugal with the rest of Europe some issues should be considered: Europe is a very complex unit (Duchesne, 2008), and each country seems to have its own consumer behavior and diverse online shopping habits (Ecommerce News, 2015). On the other hand the economic and financial crisis affected the economic power of consumers of a large number of consumers, and consequently they will not be able to use all the advantages of the digital market (Komljenovic et al. 2016).

In order to understand the reason for the low online purchases in Portugal when compared to the rest of Europe, this article attempts to uncover the direct and indirect correlations between the e-commerce adoption and other variables. A survey was conducted in order to find the real barriers that influence online purchasing for the Portuguese.

\section{LITERATURE REVIEW}

According to Eurostats (2016) around 85\% of the households in the EU have internet connection. Still according to Eurostats (2016) $71 \%$ of the individuals use it in their daily lives. On the other hand, only $60 \%$ of the 
Portuguese use the internet on a daily basis which compares with $74 \%$ that have internet access in their household. Still it is important to refer that there was a growth, between 2008 and 2016, of 43\% to 71\% in EU and $29 \%$ to $60 \%$ in Portugal. Lastly, it should be mentioned that the average of individuals who have never used the internet in the UE and Portugal was according to the study of $14 \%$ and $26 \%$, respectively.

According to a report in eMarketer (2015) the UK, Germany and France are Europe's three largest ecommerce markets. In 2014, they jointly accounted for just over $60 \%$ of all digital turnovers in the region. The UK alone claimed $30.0 \%$ of digital sales, the report found. Russia was mentioned as the fastest-growing European market in 2014. Spain ranked fifth by this measure, with $4.0 \%$ of regional sales. On the other hand Portugal was not even referred. In fact the proportion of web shoppers varied widely across member states, for example ranging from $87 \%$ in the United Kingdom to 18\% in Romania (Briggs, 2016). Those numbers revealed the variance between European countries in the ecommerce practice. This justifies and demonstrates the urgency to understand each nationality's behaviour and their motivations, as well as barriers to buying online.

The main cause for many consumers in Central, Eastern and Southern Europe to be less prone to buy online is the user-friendly digital purchasing option not offered by some national e-retailers. It's clear that Europe's digital transformation is just beginning. According to eMarketer 2015's report, it is estimated that digital platforms account for just $7.3 \%$ of overall retail sales value in Western Europe - and in Central and Eastern Europe, that slice should be even smaller: $2.8 \%$. This was the reason we decide to understand the difference between the behavior of Portuguese and European online consumers.

In 2000, only $6.7 \%$ of the worlds' population had used the internet. Nowadays nearly $40.4 \%$ had been reported using it. The growth had been constant and was expected to continue for the following years (Wellman \& Haythornthwaite, 2001). Also a few years ago the Mindshare Digital Normalness Index (MDNI, 2003) tried to understand the motivations of the users from 33 nations around the world. The study compared the behavioural factors of information seeking: self-expression and communication, entertainment and transition with the infrastructure score of the country. The infrastructure score depends mainly on the connection speed and the number of connections made with laptops and computers. This value is very important to differentiate countries according to their practical internet usage. Although Portugal presents an average infrastructure score, it manages to have an above normal score in all 
variables except entertainment, achieving the first place in information seeking, for instance. The study only focuses on internet users and not on the general population. In the Portuguese case, there is a high level of internet penetration but there are still a great number of entities who don't use internet along with e-commerce, and these individuals should also be considered and studied. Still, the study is very useful in concluding that the e-commerce practices are not so intrinsically related to infrastructures as previously thought, being influenced by other variables more important that should also be taken into account. There is a need to evaluate the main variables and then choose those that have or can have a higher impact in the e-commerce business.

Furthermore there are not many studies evaluating Portugal's information, and so it's not easy to understand the internet usage and the ecommerce business in this country. Even though the internet use is below average, Portugal still has a good internet penetration but lacks online transitions as only $23 \%$ of the individuals have bought a service or product online in 2015. It's important to refer that, in the EU27, the mean of individuals shopping online is $43 \%$ (EuroStats, 2015).

The evolution and easiness of access to internet have altered the way many industries operate. The possibility of selling online led to a significant growth in companies' sales. Today, creating a business became such a fast and uncomplicated process that e-commerce was elevated to a very competitive level. Despite all these facts, in some cases, success doesn't come easy. The reality is that in order to prosper it is necessary to lead internet users to the companies' website and convince them to acquire the products.

With such an accessible business, presenting low costs and high number of potential customers, it's easy to understand why so many companies tried to succeed and profit with e-commerce. Every day new businesses are created with the intention of selling products or services online (Jones, 1998). To succeed in this scenario, several questions should be taken in consideration: is there an easy way to bring customers to the website? Is it possible to convince clients into buying? The first question may be answered by online or traditional marketing. Usually, the problem doesn't appear to be the capability of convincing users to visit the website. The natural dilemma seems to be how to convince users into buying online. Why didn't users take advantage of the benefits in buying online? In order to answer this question it is crucial to primarily understand a bit more of the e-commerce business and its adoption variables.

Many authors made several findings on what influences the consumer into buying and what are the barriers to this practice (Thompson et al. 
1999, Brynjolfsson \& Smith 2000, Koufaris \& Hampton-Sosa 2004). Davis (1989) created a model to predict and explain the system usage based on two variables: Perceived Usefulness and Perceived Ease of Use. Based on this model, it was possible to understand why some people accepted a new technology, in this case the e-commerce, and why others rejected it. This model is one of the most used to predict technology adoption (Gefen \&Straub, 2000). Although some authors criticized this model on its lack of practical or questionable heuristic value (Hindman, 2000), it was still used by many researchers (Parker et al., 1989, Venkatesh \& Davis, 2000).

Consumers had the advantage of comparing online products from different websites through a fast and easy research using web search engines such as Google or Yahoo! (Rotter, 1967). The competition felt in e-commerce was of an extremely high level given that the consumer had the ability to transform its buying process into an efficient and almost effortless choice (Koufaris \& Hampton-Sosa, 2004). This perspective was presented by Koufaris \& Hampton-Sosa (2004) and Rotter (1967) that claim that efficiency results primarily because of the cost of the information as well as the cost and time required of acquiring information was so low.

Brynjolfsson \& Smith (2000) discovered that the prices online, compared to the traditional retail outlets, were $8 \%$ to $15 \%$ lower. In sum, it was possible to understand that the customer had the ability of choosing where to buy, to compare multiple products with no effort and lower prices and choosing the delivery place, reducing even more the effort of picking it up.

With another point of view, Atif (2002) found that the five most common reasons to buy online were reduction of shopping time, timing flexibility, less physical effort, saving of aggravation and the opportunity to engage in impulse buying or directly responding to an advertisement.

Perceived ease of use is defined as the degree to which a person believes that using a particular system would be free from effort (Davis, 1989, Davis, Bagozzi et al., 1992). Davis studied the impact of the ease present in computer usage and the internet practice and concluded that there was a positive and significant correlation between the two. This phenomenon is easy to understand as in most systems, the easier the practice, the less effort will be required to the users, thereby increasing the likelihood of usage by the individuals. In order to simplify the online experience, different browsers are created resulting in user directed programs and a great number of browsers from which users can choose. These developments affect the ease to use the internet and, therefore, the ecommerce as the shopping must be done in a web browser. One can expect 
that if used in the online purchases example, the e-commerce' perceived usefulness will display a significant and positive correlation with the ecommerce activities, since the online experience of an individual has been proven to be positively correlated with online purchasing practices (Miyazaki \& Fernandez, 2000, Thompson, 2001)).

Perceived usefulness can be defined as the degree to which a person believes that the use of a particular system would enhance his or her job performance (Davis, 1989, Davis, Bagozzi et al., 1992). This variable has a positive influence on the adoption of technology. Therefore, if used in the example of the e-commerce, one could expect that the e-commerce perceived usefulness has a significant and positive correlation with ecommerce activities (Gefen \& Straub, 2000).

On the opposite side of the situation, a survey from Thompson (2001) concluded that over $70 \%$ of the internet users in Singapore that didn't shop online find it difficult to judge product's or service's quality, didn't feel comfortable shopping online and didn't feel secure giving their credit card number through the internet. This survey was very useful in understanding that the non-practitioners of the e-commerce feel insecure about the outcome of the transaction. This can be explained by some concerns about several risks like credit card theft and product swindle, or through an unease in this recent and still not fully known commerce (Levin et al., 2003). Levin et al. (2003) stated that the lack of ability to see and touch the product, as well as the absence of personal service was a great disadvantage to the online commerce. Authors even concluded that these handicaps are greater in some products, usually the ones that had hightouch needs like clothing, and inferior in others, such as computer software or books. Still the importance of tactile information such as smell, vision, touch, sound and even taste must be considered as it was present in offline shopping (Childers et al., 2001). The best example of businesses that had important tactile information was experienced in groceries stores or florists. Even haptic attributes like texture, hardness, temperature or the weight must be reflected as a disadvantage in online commerce (Childers et al. 2001). These handicaps must be taken into consideration since a consumer will become frustrated with his online purchasing experience and feel less confident in the product if a barrier to direct experience is felt (Childers et al. 2001). As Komljenovic et al. (2016, p: 3) mentioned: "Our visual sense is not the most powerful in getting us interested to buy, because visual images are far more effective and memorable when they are coupled with another sense - like sound or smell”. Lardner (1999) blames this occurrence on the perception of a great number of risks inherent in ecommerce. This author states that there is a great lack of public 
confidence, which in turn poses a serious impediment to full-scale electronic commerce. Pavlou (2003) describes perceived risk as a subjective belief of suffering a loss in pursuit of a desired outcome. The psychological perception of these possibilities is the most important variable to be understood when exploring why so many users refused to use a technology that was so convenient and helpful (Pavlou, 2003). The perception of any type of risk in buying online is negatively correlated to future online purchases (Liebermann \& Stashevsky, 2002). This relationship is found in apprentice and experience internet users although higher online experience will decrease the perceptions of the risks (Miyazaki \& Fernandez, 2000, Thompson, 2001, Liebermann \& Stashevsky, 2002). This risk variable should be decomposed into the many risks, or sub-risks, and fears that users suffer from (Bettman 1973, Lardner 1999, Garbarino \& Strahilevitz 2004). Bettman (1973) separates it into financial, physical, psychological and social. Others even considered the technological risk, which is the fear of technological complicated innovations, usually undergone by people of higher ages (Bélanger \& Carter, 2008). Corbitt et al. (2003) divides the risks into performance, financial, social, and psychological and time risks. It's important to separate the multiples types of risks as to fully understand the actions that should be made in each case to increase the usage of the e-commerce. For instance, if a clutch of people presents a higher perception of privacy risks, the solution might be to convince them that they will have confidentiality when visiting the website or buying online. But if the problem is a higher perceived product risk, the retailers will have to gain the users' trust and confidence in order to sell. The following table (table 1) resumes the advantages and disadvantages of the e-commerce for the companies and for the consumers. 


\section{Luís Cavadas, Susana Costa e Silva, Carla Martins e António Andrade}

\section{Table I}

Advantages and disadvantages of E-commerce.

\begin{tabular}{|c|c|}
\hline \multicolumn{2}{|c|}{ Company } \\
\hline Advantages & Disadvantages \\
\hline $\begin{array}{l}\text { Fast and uncomplicated to } \\
\text { create }\end{array}$ & High competitive level \\
\hline $\begin{array}{l}\text { High number of potential } \\
\text { consumers } \\
\text { Low cost to create and } \\
\text { maintain }\end{array}$ & $\begin{array}{l}\text { Need to convince consumers into } \\
\text { buying }\end{array}$ \\
\hline \multicolumn{2}{|c|}{ Consumer } \\
\hline Advantages & Disadvantages \\
\hline Fast, free and easy information & Credit card theft \\
\hline Efficient and effortless process & $\begin{array}{l}\text { Lack of ability to smell, touch, hear, } \\
\text { taste and see }\end{array}$ \\
\hline Cheaper & Social Risks \\
\hline Less Physical effort & Psychological Risks \\
\hline Timing flexibility & Performance Risks \\
\hline Faster and easy to use & Time Risks \\
\hline $\begin{array}{l}\text { Possibility to answer an } \\
\text { advertisement }\end{array}$ & Financial Risks \\
\hline $\begin{array}{l}\text { Possibility of buying } \\
\text { impul sively }\end{array}$ & \\
\hline
\end{tabular}

\section{DEMOGRAPHIC VARIABLES}

\subsection{Gender}

As showed by several studies the ordinary user is usually male (Thompson \& Vivien 2000, Thompson 2001). Furthermore, in a different study, researchers conclude that women are more likely to suffer from techno stress, which means:

physical and emotional burnout caused by inability to adapt to a new technology, resulting in less perceived ease of use on computers and ecommerce practices (Thompson \& Vivien, 2000). Thompson \& Vivien (2000) also concluded that both genders find the computer to be useful, but 
men consider this technology easier to learn. This is an important consideration because the more comfortable a person is using the internet and the computer, more likely they will enjoy the e-commerce business (Gefen \& Straub, 2000). Women are more concerned with the numerous risks, like credit card theft, wrong perception of product, etc., that still exist in making an online purchase (Kehoe et al., 1998).

\subsection{Age}

Younger individuals are more likely to navigate the internet, as age has a negative relationship with internet usage (Elder et al. 1987, Zeffane \& Cheek 1993, Thompson 2001). It is also known that there is a positive relationship between internet used and online shopping, so it is expected that age would have a negative correlation with online shopping (Thompson, 2001). Younger individuals spend a lesser amount of effort when buying online and have an advantage in doing so (Sorce et al. 1990, Zeffane \& Cheek 1993). Older consumers were also more likely to suffer from techno stress (Elder et al., 1987). These differences are explained by Sorce, et al. (1990) that concluded that younger respondents considered online shopping as more convenient than older individuals. A positive correlation is found between the variable age and the four types of perception of risks previously identified (Liebermann \& Stashevsky, 2002).

\subsection{Educational levels}

The difference in internet practices between high formal education and none/low education in inferior ages is minimum and has no significant meaning (Loof \& Seybert, 2009). Igbaria (1993) also concludes that with higher educational levels there is less probability that the individual will suffer from techno stress, thus facilitating the computer usage. Two different studies, one from Alex Susskind (2004) and other from Yehoshua Liebermann \& Stashevsky (2002), found a positive correlation between educational level and online buying. On another point of view, Larnder (1999) and Thompson (2001) found no traces of relationship between the two variables throughout their studies. Three types of risks have been proven to have a negative correlation with education (Liebermann \& Stashevsky, 2002). Unfortunately, no reason is found for this occurrence (Liebermann \& Stashevsky, 2002). 


\subsection{Income}

There has been studies that conclude that income have a positive relationship with online shopping (Bagchi \& Mahmood, 2004). However, there aren't many studies that approach this variable in a rightful way as it has to be isolated from education, age, perception of risks, and other factors that may be indirectly meddled in the intended results.

\section{MODEL DEVELOPMENT}

Previous studies indicate that the perception of any type of risks in buying online affected negatively the e-commerce practices of an individual (Thompson 2001,Liebermann \& Stashevsky 2002, Lim 2003, $\mathrm{Kim}$ et al. 2008). Some authors state that the perception of any type of risks are the main reason why the e-commerce business hasn't been following the high internet penetration rate (Pavlou, 2003). Thus, this construct should be considered the most important barrier to online consumption. The different kind of sub-risks are influenced by different variables (Liebermann \& Stashevsky, 2002). It is therefore expected that the perception of online risks will be negatively correlated with the ecommerce practices. Thus, we will propose the following hypothesis:

H1: There is a significant negative impact of Perceived Risk variable on E-commerce practices

The online experience of an individual has been debated to have a positive correlation with the online shopping practices (Thompson 2001, Liebermann \& Stashevsky 2002, Garbarino \& Strahilevitz 2004), so, more experienced web users are more likely to be involved in e-commerce practices. Thompson (2001) found that online purchasing has a significant and positive correlation with the online activities of downloading, browsing and messaging.

Some authors state that the online experience doesn't influence the ecommerce practices directly, as it affects the perceived risk of security and privacy which are negatively correlated to online purchases habits (Miyazaki \& Fernandez 2000, Liebermann \& Stashevsky 2002, Garbarino \& Strahilevitz 2004). So, indirectly, online experience has an impact on ecommerce practices. It is therefore expected that if the internet usage becomes more ordinary around the world, the online experience of the consumers will rise and so will the online purchases. The following hypothesis will be then proposed:

H2: There is a significant positive impact of Online Experience on Ecommerce practices 
Perceived ease of use of the e-commerce practices is expected to have a positive relationship with the online purchasing habits since the easier and free of effort the use of a system is, the more likely it is to be adopted (Davis 1989, Davis, Bagozzi et al. 1992, Gefen \& Straub 2000). The technological acceptance model, also known as TAM, is used in many different studies (Venkatesh \& Davis 1994, Gefen 1997, Venkatesh \& Davis 2000, Perea 2004) and is one of the most important models to understand and predict technology adoption. The Perceived Ease of Use construct translates in the easiness of an individual in buying online spending less effort and time.

Therefore we propose the following hypothesis:

H3: There is a significant positive impact of Perceived Ease of Use one E-commerce practices

The perceived usefulness of the e-commerce practices is expected to present a positive correlation with the online purchasing habits of an individual (Davis 1989, Adams et al. 1992, Davis, Bagozzi et al. 1992). Like the previous construct Perceived Ease of Use, the Perceived Usefulness is presented in the technological acceptance model. The model explains that the perceived usefulness of a technology is one of the instruments to determine and predict technology adoption. Like the previous construct, the perceived usefulness is used by many authors (Adams et al. 1992, Chin \& Todd 1995). Hence, we propose:

H4: There is a significant positive impact of Perceived Usefulness on Ecommerce practices.

The theoretical model proposed is presented below in figure 1.

Figure I

Proposed Theoretical Model

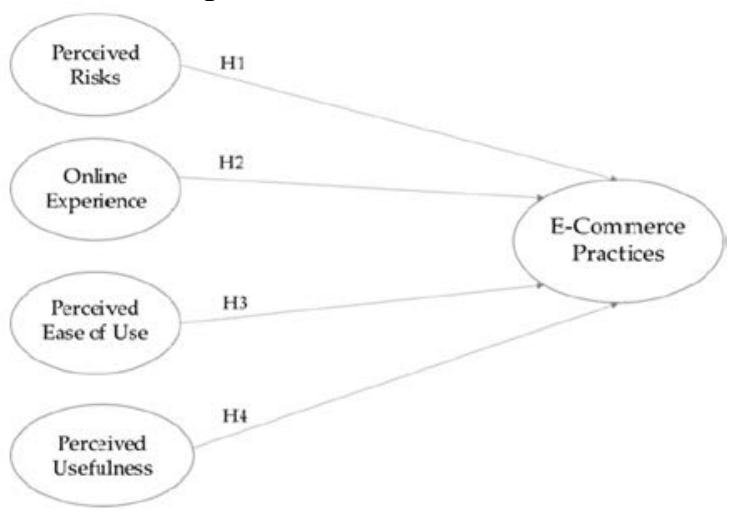




\section{METHODOLOGY}

The chosen method of data collection was the online questionnaire. This technique ensured an advantage in time, cost, efficiency and convenience of the respondents compared to the other deliberated methods. Many authors, researching similar subjects, had chosen the online questionnaire as their method of data collection (Thompson et al. 1999, Liebermann \& Stashevsky 2002, Verhagen \& Dolen 2011). The survey was based in other studies and translated from English into Portuguese to ensure the native language of the respondents. As Harzing \& Maznevski (2002) stated an instrument developed in one culture and language has to be translated into the language of the second culture, while at the same time preserving and maintaining the meaning of the original, since presenting a English survey to Portuguese individuals could alter the understanding of the questions, the answers and the results. Five constructs and five demographic variables were chosen. The model was tested using a Linear Regression. The survey was distributed within a sample of convenience (using the online social network Facebook and through e-mails). Before distribution, two pre-tests were made to ensure that the questionnaire didn't have interpretation problems, errors or miss translations. Each test was conducted on 10 respondents.

To analyze the proposed relationships, five constructs were used: Perceived Risks; Online Experience; Perceived Ease of Use; Perceived Usefulness; E-Commerce. The questions of the online survey were presented in the following table (table 2), to understand the construct components. 


\section{Table II}

\section{Items of the constructs used in the online survey}

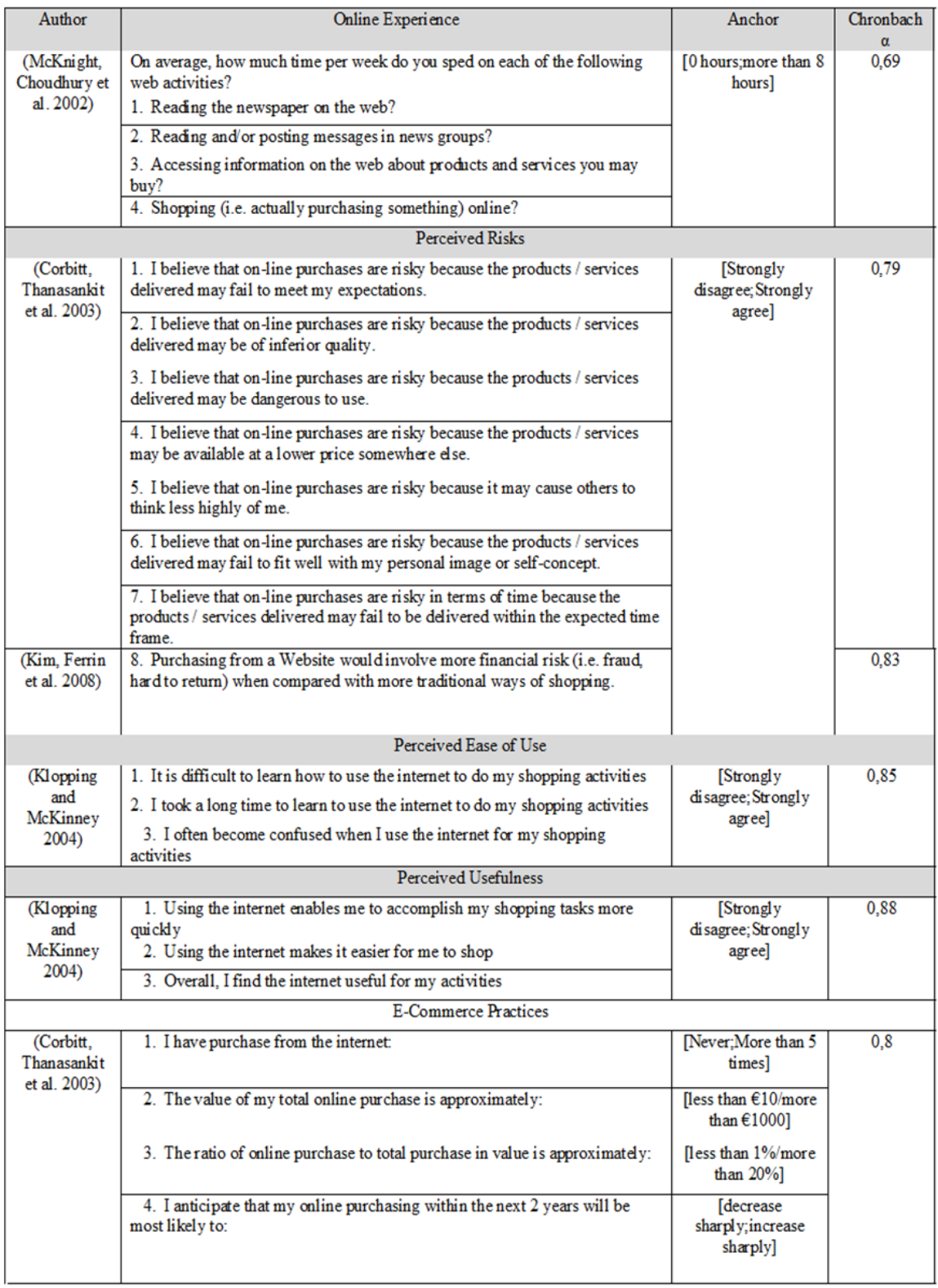


The Online Experience construct from the McKnight et. al. survey (2002) used a 7 Likert scale identical to the one used in this article. The authors reported a Cronbach for this construct equal to 0.69. This construct was measured through four questions regarding the number of hours that each individual spent on a weekly basis in four online practices. In order to measure the perception of risk we relied on the scale proposed by Corbitt et al. (2003), which consisted of seven questions. In order to add the payment risk, another question was added from Kim et. al. (2008). The Perceived Ease of Use and the Perceived Usefulness constructs were adopted from the Klopping and McKinney (2004) study. The remaining construct - E-Commerce - was based on Corbitt et. al. (2003) study.

\section{RESULTS}

The collected sample is composed by 101 inquiries which included $53.1 \%$ answers from female and $46.9 \%$ from the male gender with ages comprehended between 15 and 82 years old (average $=31.4$ years old). Around $80 \%$ of participants have higher education. Most participants are single (76\%) and professionally active (77\%).

\subsection{Exploratory Factor Analysis}

An exploratory factor analysis was conducted in order to measure the relationship between the observed and the unobservable variables and thus verify the hypothesis that the selected items are associated with specific factors. The factor loading of each question represents the scales' validation for the analysis and measurement of specific constructs, demonstrating the correlation between the original variable and the factors (Hair et al., 2006). According to Hair (2006) the value of the factor loadings must be higher than \pm 0.4 , being minimally accepted near this limit (Park, 2006). It is important to refer that all this statements are based on a significance level of 0.05 (Hair et al., 2006).

The following table (table 3) presents the collected factor loadings for each question. 


\section{Table III}

Results from the Confirmatory Factor Analysis

\begin{tabular}{|c|c|c|c|c|c|}
\hline Construct & Abbreviation & Question & $\begin{array}{c}\text { Factor } \\
\text { Loading }\end{array}$ & $\begin{array}{c}\text { Cronbach's } \\
\text { Alpha }\end{array}$ & $\begin{array}{l}\mathrm{N}^{\circ} \text { of } \\
\text { Items }\end{array}$ \\
\hline \multirow{4}{*}{ Online Experience } & \multirow{4}{*}{$\mathrm{OE}$} & OE 1 & $-0,487$ & \multirow{4}{*}{0,716} & \multirow{4}{*}{4} \\
\hline & & OE2 & 0,490 & & \\
\hline & & OE3 & 0,535 & & \\
\hline & & OE4 & 0,587 & & \\
\hline \multirow{8}{*}{ Perceived Risks } & \multirow{8}{*}{ PR } & PR1 & $-0,675$ & \multirow{8}{*}{0,819} & \multirow{8}{*}{8} \\
\hline & & PR2 & $-0,573$ & & \\
\hline & & PR3 & $-0,596$ & & \\
\hline & & PR4 & $-0,649$ & & \\
\hline & & PR5 & 0,737 & & \\
\hline & & PR6 & 0,622 & & \\
\hline & & PR7 & 0,517 & & \\
\hline & & PR8 & $-0,544$ & & \\
\hline \multirow{3}{*}{ Perceived Usefulness } & \multirow{3}{*}{ PU } & PU1 & 0,649 & \multirow{3}{*}{0,796} & \multirow{4}{*}{3} \\
\hline & & PU2 & 0,608 & & \\
\hline & & PU3 & 0,583 & & \\
\hline \multirow{3}{*}{ Perceived Ease of Use } & \multirow{3}{*}{ PEU } & PEU1 & $-0,559$ & \multirow{3}{*}{0,821} & \\
\hline & & PEU2 & 0,624 & & \multirow[t]{2}{*}{3} \\
\hline & & PEU3 & 0,588 & & \\
\hline \multirow{4}{*}{ E-Commerce } & \multirow{4}{*}{$\mathrm{EC}$} & $\mathrm{EC} 1$ & 0,769 & \multirow{4}{*}{0,855} & \multirow{4}{*}{3} \\
\hline & & $\mathrm{EC} 2$ & 0,669 & & \\
\hline & & $\mathrm{EC} 3$ & 0,717 & & \\
\hline & & $\mathrm{EC4}$ & 0,374 & & \\
\hline
\end{tabular}

As it can be observed, almost all of the chosen questions achieved a factor loading value superior to 0.4 . The only one that did not meet this standard was the EC4, fact that resulted in its exclusion from the ECommerce construct. To validate the constructs, a reliability analysis was performed concerning each one of them. The output enabled the validation of all constructs with the Cronbach's Alpha superior to 0.70 as represented in table 3. A bivariate correlation was executed in all five constructs, measuring the degree of relationship between all the independent variables and the dependent variable e-commerce habits (Mertler \& Vannatta, 2002), as depicted in table 4 . 
Table IV

Correlation between the E-Commerce and the other constructs

\begin{tabular}{|c|c|c|cc|}
\hline \multicolumn{5}{|c|}{ Correlation } \\
\hline Construct & $\begin{array}{c}\text { Perceived Ease of } \\
\text { Use }\end{array}$ & $\begin{array}{c}\text { Perceived } \\
\text { Risk }\end{array}$ & $\begin{array}{c}\text { Perceived } \\
\text { Usefulness }\end{array}$ & $\begin{array}{c}\text { Online } \\
\text { Experience }\end{array}$ \\
\hline $\begin{array}{c}\text { Pearson } \\
\text { Correlation } \\
\begin{array}{c}\text { Sig. (2- } \\
\text { tailed) }\end{array}\end{array}$ &, $306^{* *}$ &,$- 517^{* *}$ &, $489^{* *}$ &, $616^{* *}$ \\
\hline $\mathrm{N}$ & 0,004 & 0 & 0 & 0 \\
\hline
\end{tabular}

*. Correlation is significant at the 0.05 level (2-tailed).

\subsection{Demographics and model variables}

Before testing the model, bivariate ordinal correlations were computed between each demographic variable and all the variables in the model (table 5).

Table V

Correlations between the constructs and the demographic variables

\begin{tabular}{|c|c|c|c|c|c|}
\hline & & Gender & Age & Education & Income \\
\hline \multirow{4}{*}{ Online Experience } & Correlation &,- 058 &,- 106 & ,178 & ,280** \\
\hline & $\mathrm{p}$ & ,572 & 303 & ,082 & ,007 \\
\hline & $\mathrm{N}$ & 97 & 97 & 97 & 91 \\
\hline & Correlation &,- 024 &,- 065 & ,010 &, $237^{*}$ \\
\hline \multirow[t]{3}{*}{ Perceived Usefulness } & $\mathrm{p}$ & 818 & ,529 & 919 & ,024 \\
\hline & $\mathrm{N}$ & 97 & 97 & 97 & 91 \\
\hline & Correlation &,- 161 & ,080 &,$- 206^{*}$ &,- 083 \\
\hline \multirow[t]{3}{*}{ Perceived Ease of Use } & $\mathrm{p}$ & 123 & ,446 & ,047 & ,440 \\
\hline & $\mathrm{N}$ & 93 & 93 & 93 & 89 \\
\hline & Correlation & ,142 & 189 &,$- 249^{*}$ &,- 068 \\
\hline \multirow[t]{3}{*}{ Perceived Risks } & $\mathrm{p}$ & 181 & 073 & ,017 & ,534 \\
\hline & $\mathrm{N}$ & 91 & 91 & 91 & 87 \\
\hline & Correlation &,- 204 &,- 013 & ,046 & ,387** \\
\hline \multirow[t]{2}{*}{ E-commerce Habits } & $\mathrm{p}$ & ,056 & 901 & 671 & ,000 \\
\hline & $\mathrm{N}$ & 88 & 88 & 88 & 83 \\
\hline
\end{tabular}

Online Experience. Contrary to initial expectations, among demographic variables, only income is significantly correlated with online experience. This positive correlation found between the demographic 
variable income and the Online Experience construct was not anticipated because there were no studies previously identifying it. This may happen due to the use of new technologies such as tablets and smartphones that allow the user to surf the internet in almost any place in the world. Despite its benefits, these technologies were still expensive products and not affordable by everyone. One can then infer that individuals with financial capacity to buy these products will, in general, have more intensive internet experience. Besides, income is normally associated with higher levels of education, enabling a more complex use of the internet.

Perceived Usefulness. There was also a positive correlation between perceived usefulness and income, which was not surprising. Low income does not allow intensive consumption, neither offline nor online. Therefore, e-commerce is useless.

Perceived Ease of Use. The expected positive correlation found with the education variable lead to the conclusion that higher educated individuals perceived a greater ease to use of the e-commerce. More educated individuals are more prone to use technology and more prepared to use it in more expanded ways.

Perceived Risks. A negative correlation found, appeared to demonstrate that users with higher educational degrees felt less apprehensive about using e-commerce, which was expected, given that education prepares consumers to react more adequately to any problem which might arise from online purchase in order to solve it.

E-Commerce Practices. As expected there was a significant positive correlation between income and the E-Commerce construct, for the same reasons mentioned above.

Conceptual model test

A linear regression was used in order to test the model expected relationships simultaneously (Landau and Everitt, 2004). The model presented the construct E-Commerce as the dependent variable and the Perceived Risk, Perceived Usefulness, Perceived Ease of Use and Online Experience as the independent variables (figure 1). A linear regression is a method of analysis for assessing the strength of the relationships between each of a set of independent variables, and a single response, also known as dependent variable (Susskind, 2004).The model presented a $\mathrm{R}^{2}$ of 0.517 , demonstrating how much variation of the dependent variable can be explained by the independent variables, in other words, $51,7 \%$ of the answers regarding the E-Commerce construct, could be explained by the chosen independent variables (Susskind, 2004). The model presented in figure 2 shows the standardized coefficients Beta above and the t-value below the arrow, representing each relationship. 


\section{Figure II}

Model of the constructs' relationship with the E-commerce Practices

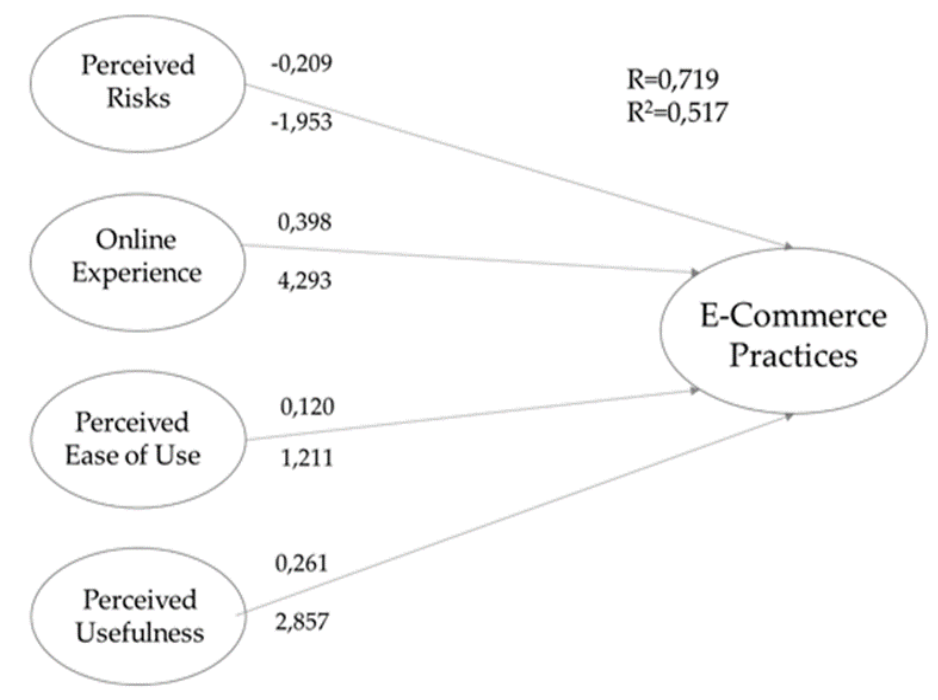

Whereas Online Experience and Perceived Usefulness are clearly good predictors of e-commerce practices, Perceived Ease of Use is not and Perceived Risks is in a borderline position, with a beta coefficient of 0.209 ( $\mathrm{t}=-1.953 ; \mathrm{p}=0.054)$.

\section{DISCUSSION}

\subsection{Portuguese consumer}

The sample of this study is in line with the profile of the typical Portuguese internet user, young and highly educated (Obercom, 2014). These demographic characteristics are different from those of the general population, that has an average of 44 years old (being $42 \%$ older than 50 ) and an average educational level well below the European countries average (OECD, 2014).

Results have shown that the most important factors for the explanation of e-commerce habits among internet users are online experience and perceived usefulness of e-commerce. We have also found that these variables are both negatively correlated with age and positively correlated with income. Younger internet users and users with higher income tend to perceive e-commerce as more useful and easier to use, making them more able to purchase online. This brief summary may, at least in part, explain 
the Portuguese inhibition to use online commerce. In fact, the majority of the Portuguese population has relatively low income, when compared with most western countries (OECD, 2016). Besides, Portugal has an aging population. These factors create unfavourable conditions for e-commerce in Portugal.

Descriptive statistics have shown that while the average perception of e-commerce usefulness is high, average online experience is relatively low and should be regarded as problematic to e-commerce adoption, especially because this is a sample of internet users. This suggests that many people may use the internet in a somehow rudimentary way, avoiding complex actions, namely buying online. It is however predictable that, in the medium and long term, as generations, that are presently the youngest and the most prone to use technology, become the main consumers in the Portuguese market, e-commerce should experience significant changes.

The variable perceived risks has also proved to be statistically significant as predictor of e-commerce habits, if we adopt a $90 \%$, instead of 95\%, confidence level. A deeper analysis has shown that four of the eight types of risks are troublesome: fear that the product/service will fail to meet their expectations, fear that the product/service will be of inferior quality, the fear that the product/service will fail to be delivered within the expected time frame and fear of financial risks such as fraud, difficulty in devolution, etc. These must be considered and treated as main barriers to the e-commerce growth in Portugal. It was therefore imperative to ask these questions: Did the Portuguese e-commerce business failed at this point? Did the Portuguese have too high expectations? Further studies should be made in order to understand this phenomenon and to achieve the most efficient way to resolve them.

Since Portugal was situated in the corner of Europe, without many terrestrial passages for product importation, the following issues were important because the e-commerce was a global business. The delivery cost and time may be superior in Portugal due to its geographical position, if the company was not Portuguese. It was important to ask: Did it take longer to deliver the products from other countries? Was the financial risk greater? Did the quality worsen?

\subsection{Findings}

This article had helped to further understand the Portuguese variables for online purchases. Online experience and perception of usefulness had been proven to have a positive impact over e-commerce practices. In this study, ease of use, did not prove to be a predictor of e-commerce practices in the Portuguese population. 
Regarding the demographic variables it was important to refer that the high age of the Portuguese increased the perception of risks and lowered the e-commerce consumption. The age variable also had a negative impact in the online experience, where younger individuals seemed to have higher values, and thus higher e-commerce practices. The correlation found between the educational level and the Perception of Ease of Use and the Perception of Risks results in an indirect relationship with the e-commerce practices and should be studied. It was imperative to refer that the correlations found between education and Perceived Ease of Use and Perceived Risk may be of great importance in order to understand if the education levels do interfere with the online purchasing habits of an individual. For last, the gender variable seemed to have no influence whatsoever in any of the discussed variables. It should be determined if the online experience of both genders was, in fact, like it was found in this sample, equivalent, by creating a new study where their online experience was compared.

In sum, although the Portuguese might seem to spend a great number of hours seeking information online, the perception of risks seemed to still inhibit the online shopping practice. The demographic characteristics, such as age and income of the Portuguese, seemed to aggravate the perception of the risks associated with the e-commerce habits, reducing its practice. For that is extremely mandatory to empower consumers which means to provide them with proper regulatory framework and effective tools that will enable them to make informed and responsible decisions about buying products and services (Komljenovic et al., 2016). An alternative will be the availability of online assistance and efficient customer support. Online websites should be made hassle-free through easy to understand language. Special discounts may be offered to consumers making purchases online. People are afraid of data confidentiality in online websites. Support can be offered to consumers to overcome their fears (Khare, 2016).

\subsection{Limitations \& Suggestions for Future Studies}

The number of inquiries that were analyzed can be considered relatively low in order to determine if the findings were, or not, relevant to the Portuguese habits. The amount of answers from individuals with lower education was also relatively low. In order to ensure that the results represented the Portuguese reality, a study should be made with a greater number of respondents to guarantee that the marital status, age and educational levels have a greater diversity 
A study could be made in order to understand if the location of Portugal worsens the quality or costs of the products or services sold online and thus resulting in higher levels of perceived risks.

\section{REFERENCES}

Adams, D., Nelson R. \& Todd, P. (1992). Perceived usefulness, ease of use and usage of information technology: a replication. MIS Quarterly $16(2): 227-247$.

Atif, Y. (2002). Building trust in e-commerce. IEE Internet Computing (January):18-24.

Bagchi, K. \& M., Mahmood (2004). A longitudinal study of a business model of on-line shopping behavior using a latent growth curve approach. AMCIS 2006 Proceedings: Paper 240.

Bélanger, F. \& L., Carter (2008). Trust and risk in e-government adoption. Strategic Information Systems 17: 165-176.

Bettman, R. (1973). Perceived risk and its components: a model and empirical test. Marketing Research 10(2): 184-190.

Bhatnagar, A.,S., Misra \& H.,. Rao (2000). On risk, convenience, and internet shopping behavior. Communications of the ACM 43(11): 98105.

Briggs, B. (2016). Europeans grow more comfortable shopping online. Internet Retailer, portal to e-commerce intelligence, January 22, 2016.

Brynjolfsson, E. \& M., Smith (2000). Frictionless commerce? - a comparison of internet and conventional retailers. Management Science 46(4): 563-585.

Childers, T. L., C., Carr, J. Peck \& S., Carson (2001). Hedonic and utilitarian motivations for online retail shopping behavior. Retailing 77: 511-535.

Chin, W. \& P., Todd (1995). On the use, usefulness, and ease of use ofstructural Equation Modeling in MIS Research: A Note of Caution. MIS Quarterly 19(2): 237-246.

Corbitt, B., T., Thanasankit \& H., Yi (2003). Trust and e-commerce: a study of consumer perceptions. Electronic Commerce Research and Applications 2: 203-215.

Davis, D. (1989). Perceived usefulness, perceived ease of use, and user acceptance of information technology. ABI/INFORM Global 13(3): 317-340. 
Davis, D., R., Bagozzi \& P., Warshaw (1992). Development and test of a theory of technological learning and usage. Human Relations 45(7): 660-686.

Division, I. T. U. I. a. U. N. P. (2015). Internet live stats.

EcommerceNews [Online]. (2015) Online shopping habbits in Europe: this is how europeans like to shop.

Eurostat 2014, 2015 and 2016, online service

Duchesne, S. (2008). Waiting for a european identity ... reflections on the process of identification with europe. perspectives on european politics and society special issue. European Identities 9(4): 397-410.

Elder, B., E., Gardner \& S., Ruth (1987). Gender and age in technostress: effects on white-collar produtivity. Government Finance Review 3(6): $17-21$.

eMarketer (2015). European ecommerce turnover to hit $€ 477$ billion this year . eMarketer, Retail \&Commerce September 14, 2015.

Garbarino, E. \& M., Strahilevitz (2004). Gender differences in the perceived risk of buying online and the effects of receiving a site recommendation. Business Research 57: 768-775.

Gefen, D. (1997). Building users' trust in freeware providers and the effects of this trust on users' perceptions of usefulness, ease of use and intended use. Ph.D. Dissertation, Georgia State University.

Gefen, D. \& D., Straub (2000). The relative importance of perceived ease of use in is adoption: a study of e-commerce adoption. Association for Information Systems 1(8).

Hair, J., W., Black, B., Babin, R., Anderson \& L., Tatham (2006). Multivariate data analysis. Prentice Hall, Upper Saddle River, New Jersey 6.

Hindman, B. (2000). The rural-urban digital divide. Journalism and Mass Communication Quarterly 77(3): 349-360.

Khare, A. (2016). Consumer shopping styles and online shopping: an empirical study of indian consumers. Global Marketing 29(1): 40-53.

Kehoe, C., J. Pitkow \& K., Morton (1998). Eighth WWW user survey.

Kim, J., D.. Ferrin \& H., Rao (2008). A trust-based consumer decision model in electronic commerce: the role of trust, risk, and their antecedents. Decision Support Systems 44(2): 544-564.

Komljenovic, A. \& K., Brana (2016). A study of marketing techniques and consumer protection in the regulatory framework of the european union. Social Science and Humanity, 6(9): 710-713.

Koufaris, M. \& W., Hampton-Sosa (2004). The development of initial trust in an online company by new customers. Information \& Management 41: 377-397. 
Lardner, J. (1999). I know what you did last summer and fall. US News \& World Report 126(15): 55.

Levin, M., C., Heath \& I., Levin (2003). Product category dependent consumer preferences for online and offline features and their influence on multi-channel retail alliances. Electronic Commerce Research 4(3): 85-93.

Liebermann, Y. \& S., Stashevsky (2002). Perceived risks as barriers to Internet and e-commerce usage. Qualitative Market Research: An International Journal 5(4): 291-300.

Lim, N. (2003). Consumers' perceived risk: sources versus consequences. Electronic Commerce Research and Applications (2): 216-228.

Loof, A. \& H., Seybert (2009). Industry, trade and services, EuroStat.

McKnight, H., V., Choudhury \& C., Kacmar (2002). developing and validating trust measures for e-commerce: an integrative typology. Information Systems Research 13(3): 334-359.

Mertler, A. \& R., Vannatta (2002). Advanced and multivariate statistical methods - practical applicantions and interpretations. Pyrczak Publishing 2: 12-22.

Miyazaki, D. \& A., Fernandez (2000). Consumer perception of privacy and security risks for online shopping. Working Paper, University of Miami.

Obercom, (2014). A Internet em Portugal - Sociedade em Rede 2014. [online] Available at:

http://www.obercom.pt/client/?newsId=548\&fileName=internet_portug al_2014.pdf [Accessed 26 Jan. 2016]

OECD (2014). Education at a Glance 2014 - OECD indicators. [online] Available at: https://www.oecd.org/edu/Education-at-a-Glance2014.pdf [Accessed 26 Jan. 2016].

OECD (2016). OECD Better Life Index. [online] Available at: http://www.oecdbetterlifeindex.org/topics/income/ [Accessed 19 May 2016].

Parker, B., H Hudson, D., Dillman \& A., Roscoe (1989). Rural america in the information age: telecommunications policy for rural development. Lahnam, MD: University Press of America 43.

Pavlou, A. (2003). Consumer acceptance of electronic commerce: integrating trust and risk with the technology acceptance model. Electronic Commerce 7(3): 69-103.

Perea, T. et al (2004). What drives consumers to shop online? A literature review. International Service Industry Management 15(1): 102-121.

Postnord [Online]. (2015). E-commerce in Europe 2015. 
Rotter, J. (1967). A new scale for the measurement of interpersonal trust. Personality 35(4): 651-665.

Sorce, P., V., Peroni \& S., Widrick (1990). Attitude and age differences in online buying. Retail \& Distribution Management 33(2).

Susskind, M. (2004). Electronic commerce and world wide web apprehensiveness: an examination of consumers' perceptions of the world wide web. Computer-Mediated Communication 9(3).

Thompson, H. (2001). Demographic and motivational variables associated with Internet usage activities. Internet Research 11(2): 125-137.

Thompson, H., \& L., Vivien (2000). Gender difererences in internet usage and task preferences. Behaviour \& Information Technology 19(4): 283295.

Thompson, H., L., Vivien \& L., Raye (1999). Intrinsic and extrinsic motivation in Internet usage. Omega - The International Journal of Management Science 27: 25-37.

Venkatesh, V. \& F., Davis (2000). A theoretical extension of the technology acceptance model: four longitudinal field studies. Management Science 46(2): 186-204.

Venkatesh, V. \& F., Davis (1994). Modeling the determinants of perceived ease of use. Proceedings of the Fifteenth International Conference on Information Systems: 213-227.

Verhagen, T. \& W., Dolen (2011). The influence of online store beliefs on consumer online impulse buying: A model and empirical application. Information \& Management 48: 320-327.

Wellman, B. \& C., Haythornthwaite (2001). The internet in everyday Life. American Behavioral Scientist 45(3): 363-382.

Zeffane, R. \& B., Cheek (1993). Profiles and correlates of computer usage: a study of the Australian telecommunications industry. Computers in Industry 22: 53-69. 